\title{
Ocular abnormalities in morbid obesity
}

\author{
Anormalidades oculares na obesidade mórbida \\ Kuddusi Teberik, M. Tahir Eski², Sami Doğan³, Mevlüt Pehlivan³, Murat Kaya \\ 1. Department of Ophthalmology, Faculty of Medicine, Duzce University, Duzce, Turkey. \\ 2. Ministry of Health Bingöl State Hospital, Bingöl, Turkey. \\ 3. Department of General Surgery, Faculty of Medicine, Duzce University, Duzce, Turkey.
}

\begin{abstract}
Purpose: Obesity is associated with eye diseases, but the underlying structural changes and pathogenic mechanisms have not been examined in detail. Here, we assessed the effects of morbid obesity on the morphometric indices of eye disease. Methods: Morbidly obese volunteers $(n=101$, body mass index $[\mathrm{BMl}] \geq 40$ ) and healthy individuals $(n=95$, BMl: 18.50-24.99) were examined by Goldman applanation tonometry, pachymetry, and spectral domain optical coherence tomography. Intraocular pressure, anterior chamber depth, axial length, central corneal thickness, retinal nerve fiber layer thickness, central foveal thickness, and choroidal thickness were compared between groups. Results: Uncorrected intraocular pressure was significantly greater in the morbidly obese group than in the healthy control group $(15.5 \pm 2.5$ vs. $14.5 \pm 2.6 \mathrm{mmHg}$, $p=0.009$ ), whereas axial length, anterior chamber depth, and central corneal thickness did not differ between the groups. The mean retinal nerve fiber layer thickness at the temporal quadrant was reduced in the morbidly obese group (72.7 \pm 13.6 vs. $85.05 \pm 52.6 \mu \mathrm{m}, \mathrm{p}=0.024)$. Similarly, the mean retinal thicknesses at nasal and temporal $1500-\mu \mathrm{m}$ locations were lower in the morbidly obese group (346.6 \pm 18.2 vs. $353.7 \pm 18.8 \mu \mathrm{m}, \mathrm{p}=0.008 ; 323.1 \pm 20.3$ vs. $330.0 \pm 18.9 \mu \mathrm{m}$, $\mathrm{p}=0.001$ ). The mean choroidal thickness was also reduced in almost all measurement locations (fovea, temporal 500 and $1000 \mu \mathrm{m}$, and nasal 500, 1000, and $1500 \mu \mathrm{m}$ ) of the obese group $(p<0.05)$. Weight and BMI were negatively correlated with subfoveal choroidal thickness $(r=-0.186, p=0.009 ; r=-0.173$, $p=0.015)$. Conclusion: Morbid obesity is associated with elevated uncorrected intraocular pressure and signs of neuropathy and retinopathy. Obesity may thus increase the risks of glaucoma and glaucomatous optic neuropathy.
\end{abstract}

Submitted for publication: February 7, 2018

Accepted for publication: June 3, 2018

Funding: No specific financial support was available for this study.

Disclosure of potential conflicts of interest: None of the authors have any potential conflicts of interest to disclose.

Corresponding author: Kuddusi Teberik.

E-mail: kuddusiteberik@yahoo.com

Approved by the following research ethics committee: Duzce University (\#2017-063)
Keywords: Morbid obesity; Intraocular pressure; Nerve fibers; Corneal pachymetry; Anterior eye segment; Posterior eye segment

RESUMO | Objetivo: A obesidade está associada a doenças oulares, mas as mudanças estruturais subjacentes e os mecanismos patogênicos não foram examinados detalhadamente. Aqui avaliamos os efeitos da obesidade mórbida nos índices morfométricos da doença ocular. Métodos: Voluntários obesos mórbidos $(n=101$, índice de massa corporal $\geq 40$ ) e indivíduos saudáveis $(n=95$, índice de massa corporal 18,50 a 24,99) foram examinados por tonometria de aplanação de Goldman, paquimetria e tomografia de coerência óptica de domício espectral. A pressão intraocular, profundidade da câmara anterior, comprimento axial, espessura central da córnea, espessura da camada de fibras nervosas da retina, espessura foveal central e espessura da coroide foram comparadas entre os grupos. Resultados: A pressão intraocular não corrigida foi significativamente maior no grupo com obesidade mórbida do que no grupo controle saudável $(15,5 \pm 2,5$ vs. 14,5 \pm 2,6 mmHg, $p=0,009$ ), enquanto que o comprimento axial, profundidade da câmara anterior e espessura central da córnea não diferiram entre os grupos. A espessura média da camada de fibras nervosas da retina no quadrante temporal foi reduzida no grupo com obesidade mórbida $(72,7 \pm 13,6$ vs. 85, $05 \pm 52,6 \mu \mathrm{m}$, $p=0,024)$. Da mesma forma, a média das espesuras da retinianas nas localizações nasal e temporal de $1500 \mu$ foi menor no grupo com obesidade mórbida (346,6 \pm 18,2 $\mu \mathrm{m}$ vs. 353,7 $\pm 18,8 \mu \mathrm{m}$, $p=0,008 ; 323,1 \pm 20,3 \mu \mathrm{m}$ vs. $330,0 \pm 18,9 \mu \mathrm{m}, \mathrm{p}=0,001) . A$ espessura média da coroide também foi reduzida em quase todos os locais de mensuração (fóvea, temporal 500 e $1000 \mu \mathrm{m}$, nasal 500, 1000 e $1500 \mu \mathrm{m})$ do grupo obeso $(\mathrm{p}<0,05)$. Peso e índice de massa corporal foram negativamente correlacionados com a espessura da coroide subfoveal $(r=-0,186, p=0,009 ; r=-0,173$, $p=0,015)$. Conclusão: A obesidade mórbida está associada à elevada pressão intraocular não corrigida e a sinais de neuropatia e retinopatia. A obesidade pode, assim, aumentar os riscos de glaucoma e neuropatia óptica glaucomatosa.

Descritores: Obesidade morbida; Pressão intraocular; Fibras nervosas; Paquimetria corneana; Segmento anterior do olho; Segmento posterior do olho 


\section{INTRODUCTION}

Excessive accumulation of adipose tissue (obesity) can impair physical, psychosocial, and general health ${ }^{(1)}$. Obesity afflicts all age groups, from youth to old age, but there has been a particularly rapid increase in prevalence among youth and young adults ${ }^{(2,3)}$. Body mass index (BMl), calculated as weight $(\mathrm{kg}) /$ height $(\mathrm{m})^{2}$, is the most widely adopted metric for defining underweight, overweight, and obesity. The World Health Organization defines underweight as a $\mathrm{BMl} \leq 18.50$, normal weight as a BMI in the range 18.50-24.99, overweight as 25.0029.99 , obese class $I$ as $30.00-34.99$, obese class II as $35-39.99$, and obese class IIl as BMI $\geq 40$. Morbid obesity is defined as $B M l \geq 35 \mathrm{~kg} / \mathrm{m}^{2}$ along with accompanying illnesses or $\geq 40 \mathrm{~kg} / \mathrm{m}^{2}$ without weight-related illness.

Obesity is strongly related to increased morbidity and early mortality due to associated diseases such as diabetes mellitus (DM), hypertension, and cardiovascular disease ${ }^{(4)}$. Obesity is also related to various eye diseases, such as cataract, age-related maculopathy, diabetic retinopathy, and glaucoma. However, relatively few studies have examined the potential effects of obesity without associated diseases such as DM on visual health ${ }^{(5)}$. Obesity is negatively correlated with visual acuity, but the underlying eye-related problems and pathogenic mechanisms are uncertain. Ocular problems in obesity may be associated with dysfunction of both mechanical and vascular elements of the eye, possibly due to chronic oxidative stress ${ }^{(6)}$. Thus, obesity may impair visual function in the absence of associated diseases or in the preclinical stages.

To examine the effects of obesity on ocular function in the absence of obesity-related diseases, we compared intraocular pressure (IOP), anterior chamber depth (ACD), central corneal thickness (CCT), axial length (AL), retinal nerve fiber layer (RNFL) thickness, retinal thickness (RT), and choroidal thickness (CT) between morbidly obese subjects without associated diseases $\left(\geq 40 \mathrm{~kg} / \mathrm{m}^{2}\right)$ and matched healthy subjects with normal BMI.

\section{METHODS}

This study was performed at the Department of Ophthalmology and General Surgery, Düzce University Medical Faculty, and conducted in accordance with the principles of the Declaration of Helsinki. The research sample consisted of two groups. From 353 morbidly obese individuals scheduled for sleeve gastrectomy at Düzce University Medical Faculty Department of Surgery,
101 with $\mathrm{BMI} \geq 40$ without weight-related illness were recruited as study volunteers. The control group was composed of 95 non-obese adults matched for age and sex ratio with BMl values ranging from 18.50 to 24.99 . The study was approved by the institutional ethics committee and all participants provided informed consent following explanations of research protocols and goals. BMI was assessed as bodyweight in kilograms divided by body height in meters squared $\left(\mathrm{kg} / \mathrm{m}^{2}\right)$. Subject height was measured in the standing position and body weight using a digital scale. An automatic blood pressure monitor was used to assess systolic and diastolic blood pressures.

Candidates with histories of retinal disease, smoking, high alcohol consumption, IOP above $21 \mathrm{mmHg}$, systemic diseases (such as diabetes and hypertension), glaucoma, intraocular surgery, laser treatment, contact lens use, strabismus, ocular trauma, amblyopia, or cataract, as well as those with any ocular inflammation, currently receiving medical treatment for glaucoma, or having taken any prescription drugs over the past 3 months were excluded from the study.

All examines were conducted on the right eye. Each subject received a general eye examination including best corrected visual acuity test, dilated-pupil fundus examination with a 90-diopter (D) lens, and Goldman applanation tonometry. Measures of ACD, AL, and CCT were conducted using an Echoscan US 500 system (Nidek Co. Ltd, Aichi, Japan). Average CCT (measured as $540 \mathrm{~mm}$ ) was used for the corrected IOP calculation and a $0.7 \mathrm{mmHg}$ correction was made for every $10-\mu \mathrm{m}$ change. RT, RNFL, and CT were measured by spectral domain optical coherence tomography (SD-OCT, Heidelberg Engineering, Heidelberg, Germany). The CT scans were conducted using an improved SD-OCT depth-imaging method. Eye tests and OCT scans were conducted by a trained eye doctor between 09:00 and 11:00 in the morning to mitigate potential diurnal variability. The disc margin contour line was drawn manually at the inner edge of the scleral ring by determining 7 points. The RNFL measurements were determined globally $(\mathrm{G})$ and for temporal (T), superotemporal (ST), superonasal (SN), nasal (N), inferotemporal (IT), and inferonasal (IN) sectors. CT was measured as the perpendicular distance between the hyperreflective outer border of the retinal pigment epithelial layer (automatically detected by the instrument) and the manually drawn sclero-choroidal interface. The RT and CT measurements (one subfoveal, three temporal, three nasal) were obtained at $500 \mu \mathrm{m}$ intervals up to $1,500 \mu \mathrm{m}$ using the caliper system. 
All statistical analyses were conducted using the statistical package SPSS v 22.0 (SPSS Inc., Chicago, IL, USA). Group means were compared by Mann-Whitney U-test or Student's t-test as appropriate. Correlations between various clinical examination parameters and BMI were analyzed by Spearman's rank correlation test. A P $<0.05$ (two-tailed) was considered statistically significant for all tests.

\section{RESULTS}

The morbid obesity group $(n=101)$ and healthy control group $(n=95)$ were well matched for age $(35.9 \pm 11.5$ years, range $14-63$ years vs. $36.6 \pm 11.8$ years, range $14-63$ years; $p>0.05$ ) and sex ratio (68 females and 33 males vs. 67 females and 28 males; $p>0.05$ ). The mean uncorrected IOP was significantly greater in the obese group $(15.5 \pm 2.5 \mathrm{mmHg}$ vs. $14.5 \pm 2.6 \mathrm{mmHg} ; \mathrm{p}=0.009)$, whereas AL, ACD, and CCT did not differ. Demographic and clinical characteristics of the study groups are summarized in table 1.

Among morphological measures (Table 2), RNFL thickness in the temporal quadrant was significantly reduced in the morbidly obese group compared to the healthy control group $(72.7 \pm 13.6 \mu \mathrm{m}$ vs. $85.05 \pm 52.6 \mu \mathrm{m}$; $\mathrm{p}=0.024$ ), but no significant differences were found for the other quadrants. RT was also reduced in the obese group in both the nasal and temporal $1500 \mu \mathrm{m}$ regions (346.6 \pm $18.2 \mu \mathrm{m}$ vs. $353.7 \pm 18.8 \mu \mathrm{m}, \mathrm{p}=0.008 ; 323.1 \pm 20.3 \mu \mathrm{m}$ vs. $330.0 \pm 18.9 \mu \mathrm{m}, \mathrm{p}=0.001)$. Mean CT was also reduced in all measurement locations of the obese group $(p<0.05)$ except for temporal $1500 \mathrm{~mm}$ (Table 3).

There was no significant correlation between BMI and any anterior segment parameter except for uncorrected IOP (Table 4). Alternatively, weight and BMI were strongly and negatively correlated with subfoveal CT $(r=-0.186, p=0.009 ; r=-0.173, p=0.015)$. Weight and BMI were also negatively correlated with CT at nasal 500,1000 , and $1500 \mu \mathrm{m}$ locations as well as temporal 500,1000 , and $1500 \mu \mathrm{m}$ locations. Height was not associated with CT at any location (Table 5).

\section{DISCUSSION}

Uncorrected IOP was significantly elevated in morbidly obese adults without weight-related diseases, whereas corrected IOP, CCT, AL, and ACD measurements did not differ from those of healthy controls. However, the obese group demonstrated signs of retinopathy and vascular abnormalities. Thus, morbid obesity in the absence or in the preclinical stages of associated diseases may pose risks for glaucoma and other eye diseases.

Risk factors for high IOP have been extensively studied due to the strong association with glaucomatous optic nerve damage ${ }^{(7,8)}$. In The Beaver Dam Eye Study, IOP was positively correlated with $\mathrm{BMI}$ among other factors ${ }^{(9)}$. Furthermore, epidemiologic studies have reported that the increase in IOP associated with obesity is independent of age, systolic blood pressure, and diastolic blood pressure (DBP) ${ }^{(10,11)}$. Stojanov and colleagues reported that obese individuals have significantly higher IOP than that of non-obese individuals ${ }^{(12)}$, and Gunes et al. found elevated IOP in Turkish patients with $\mathrm{BMI} \geq 39^{(13)}$. Furthermore, both Gunes et al. and Jang et al. found a positive correlation between IOP and $\mathrm{BMI}^{(13,14)}$. In our study, this correlation was found to be weak. In contrast to IOP, only a small number of studies have analyzed the correlation between BMl and glaucomatous optic neuropathy. One study found that high BMl increases the likelihood of clinical glaucoma diagnosis at hospital admission $^{(15)}$. However, a case-control study found no statistically significant difference in BMI between glaucomatous and non-glaucomatous subjects ${ }^{(16)}$. Further investigations are needed to determine associations between BMl and glaucoma.

\begin{tabular}{|c|c|c|c|}
\hline Parameters & Obese & Control & $p$-value \\
\hline Age (years) & $35.9 \pm 11.5$ & $36.6 \pm 11.8$ & 0.675 \\
\hline Body mass index $\left(\mathrm{kg} / \mathrm{m}^{2}\right)$ & $48.6 \pm 40.7$ & $22.0 \pm 1.4$ & 0.001 \\
\hline $\begin{array}{l}\text { Intraocular pressure } \\
\text { (uncorrected) (mmHg) }\end{array}$ & $15.5 \pm 2.5$ & $14.5 \pm 2.6$ & 0.009 \\
\hline $\begin{array}{l}\text { Intraocular pressure } \\
\text { (corrected) (mmHg) }\end{array}$ & $14.6 \pm 2.5$ & $14.2 \pm 2.2$ & 0.208 \\
\hline Central corneal thickness $(\mu \mathrm{m})$ & $551.9 \pm 31.3$ & $544.4 \pm 30.8$ & 0.096 \\
\hline Axial length (mm) & $22.8 \pm 2.1$ & $22.9 \pm 0.8$ & 0.609 \\
\hline Anterior chamber depth (mm) & $3.1 \pm 0.4$ & $3.1 \pm 0.4$ & 0.911 \\
\hline
\end{tabular}

Table 2. Retinal nerve fiber layer (RNFL) thickness comparisons

\begin{tabular}{lrrc}
\hline Quadrant $(\mu \mathrm{m})$ & \multicolumn{1}{c}{ Obese } & \multicolumn{1}{c}{ Control } & $\boldsymbol{p}$-value \\
\hline Temporal & $72.7 \pm 13.6$ & $85.05 \pm 52.6$ & $\mathbf{0 . 0 2 4}$ \\
Temporal-superior & $143.9 \pm 24.4$ & $138.30 \pm 23.4$ & 0.108 \\
Temporal-inferior & $148.7 \pm 23.5$ & $142.80 \pm 22.8$ & 0.078 \\
Nasal & $79.9 \pm 17.3$ & $81.90 \pm 18.1$ & 0.434 \\
Nasal-superior & $113.7 \pm 25.6$ & $117.10 \pm 20.9$ & 0.309 \\
Nasal-inferior & $115.0 \pm 26.8$ & $111.20 \pm 23.9$ & 0.300 \\
Global & $103.3 \pm 12.0$ & $104.80 \pm 15.9$ & 0.467 \\
\hline
\end{tabular}


Table 3. Distribution of mean choroidal and retinal thickness at different locations in morbidly obese and control groups

\begin{tabular}{|c|c|c|c|c|c|c|}
\hline \multirow[b]{2}{*}{ Location } & \multicolumn{3}{|c|}{ Choroidal thickness $(\mu \mathrm{m})$} & \multicolumn{3}{|c|}{ Retinal thickness $(\mu \mathrm{m})$} \\
\hline & Obese $(n=101)$ & Control $(n=95)$ & $p$ & Obese $(n=101)$ & Control $(n=95)$ & $p$ \\
\hline Foveal & $329.60 \pm 67.1$ & $360.2 \pm 118.3$ & 0.026 & $222.8 \pm 23.0$ & $223.1 \pm 18.3$ & 0.926 \\
\hline Temporal $500 \mu \mathrm{m}$ & $330.80 \pm 66.0$ & $358.7 \pm 113.0$ & 0.035 & $283.7 \pm 25.0$ & $288.4 \pm 27.3$ & 0.215 \\
\hline Temporal $1000 \mu \mathrm{m}$ & $321.70 \pm 63.2$ & $347.4 \pm 108.3$ & 0.042 & $327.1 \pm 19.4$ & $332.0 \pm 22.4$ & 0.104 \\
\hline Temporal $1500 \mu \mathrm{m}$ & $314.10 \pm 60.0$ & $333.4 \pm 107.0$ & 0.119 & $323.1 \pm 20.3$ & $330.0 \pm 18.9$ & 0.001 \\
\hline Nasal $500 \mu \mathrm{m}$ & $318.40 \pm 70.2$ & $349.6 \pm 118.6$ & 0.025 & $300.0 \pm 29.2$ & $299.8 \pm 30.8$ & 0.956 \\
\hline Nasal $1000 \mu \mathrm{m}$ & $305.30 \pm 70.4$ & $348.9 \pm 113.2$ & 0.001 & $341.5 \pm 27.5$ & $347.4 \pm 23.0$ & 0.105 \\
\hline Nasal $1500 \mu \mathrm{m}$ & $286.48 \pm 70.3$ & $323.5 \pm 114.1$ & 0.006 & $346.6 \pm 18.2$ & $353.7 \pm 18.8$ & 0.008 \\
\hline
\end{tabular}

Table 4. Correlation of body mass index with clinical parameters

\begin{tabular}{lcc}
\hline & $\mathbf{r}$ & $\mathbf{p}$ \\
\hline Uncorrected intraocular pressure & 0.167 & $\mathbf{0 . 0 2 0}$ \\
Corrected intraocular pressure & 0.107 & 0.135 \\
Central corneal thickness & 0.071 & 0.322 \\
Axial length & -0.030 & 0.672 \\
Anterior chamber depth & -0.025 & 0.728 \\
\hline
\end{tabular}

$r=$ correlation coefficient.

Table 5. Correlations of choroidal thickness with weight, height, and body mass index (BMI)

\begin{tabular}{|c|c|c|c|c|c|c|c|}
\hline & Subfoveal & T500 & T1000 & T1500 & N500 & N1000 & N1500 \\
\hline \multicolumn{8}{|c|}{ Weight } \\
\hline$r$ & -0.186 & -0.189 & -0.176 & -0.156 & -0.181 & -0.249 & -0.231 \\
\hline$p$ & $0.009^{\dagger}$ & $0.008^{+}$ & $0.014 *$ & $0.029 *$ & $0.011 *$ & $0.001^{\dagger}$ & $0.001^{\dagger}$ \\
\hline \multicolumn{8}{|c|}{ Height } \\
\hline$r$ & -0.069 & -0.071 & -0.037 & -0.056 & -0.037 & -0.073 & -0.116 \\
\hline$p$ & 0.340 & 0.320 & 0.604 & 0.435 & 0.603 & 0.311 & 0.107 \\
\hline \multicolumn{8}{|c|}{ BMI } \\
\hline r & -0.173 & -0.176 & -0.172 & -0.150 & -0.180 & -0.237 & -0.208 \\
\hline $\mathrm{p}$ & $0.015^{*}$ & $0.014^{*}$ & $0.016 *$ & $0.036^{*}$ & $0.011^{*}$ & $0.001^{\dagger}$ & $0.003^{+}$ \\
\hline
\end{tabular}

$\dagger=$ correlation is significant at the 0.01 level (2-tailed); $*=$ correlation is significant at the 0.05 level (2-tailed); $r=$ correlation coefficient.

Mean corneal thickness ranges from about $537 \mu \mathrm{m}$ to $544 \mu \mathrm{m}$ in normal adults, but is thicker in ocular hypertension cases and thinner in normotension glaucoma $^{(17)}$. Bron and colleagues found that CCT correlates positively with IOP, with each $10-\mathrm{mm}$ increase in CCT associated with a $0.15-1 \mathrm{mmHg}$ increase in the $\mathrm{IOP}^{(18)}$, whereas a manometric study found that a $10-\mu \mathrm{m}$ increase in CCT predicts a $0.7 \mathrm{mmHg}$ increase in $\mathrm{IOP}^{(19)}$. In this study, we found no significant effect of obesity on the corrected IOP.
There is currently little understanding of the pathophysiology linking obesity, IOP, and glaucoma. Both 'mechanical' and 'vascular' etiologies of IOP and glaucoma may be driven by obesity. Proposed mechanical pathomechanisms include accumulation of intraorbital fat, elevated blood thickness, elevated episcleral venous pressure, and deterioration of aqueous discharge ${ }^{(20,21)}$. Additionally, eyes with naturally weak vascular flow to the optic nerve head are more prone to injury under increased or even normal $\mathrm{IOP}^{(22,23)}$. Disruption of the arterial blood supply, changes in autonomic vasoregulation, and endothelial damage associated with obesity activity may also lead to aberrant ophthalmic blood flow ${ }^{(24)}$. Another possibility is that hyperleptinemia-induced obesity can lead to oxidative injury in the trabecular meshwork ${ }^{(25)}$.

Gunes et al. reported significantly lower ACD in obese subjects compared to a control group, but there were no significant difference in AL and CCT values ${ }^{(15)}$. Moreover, Yilmaz et al. reported that AL and CCT values did not differ significantly among healthy obese individuals with BMI of class $1^{(26)}$. In our study, these parameters also did not differ between control and obese groups. Su et al. ${ }^{(27)}$ reported that the cornea is thicker in high-BMI subjects and that this leads to higher IOP. In contrast, we also found no difference in corrected IOP between groups, although in accord with a previous study we did find a significant increase in unadjusted IOP values ${ }^{(28)}$. Glaucoma is less likely to develop in individuals with high $\mathrm{CCT}^{(15)}$. However, we believe that glaucomatous optic neuropathy may develop due to ischemic and mechanical effects caused by obesity, even though there is no difference in corrected IOP.

In our study, the morbidly obese group exhibited significant thinning of the RNFL in the temporal quadrant . Similarly, Dogan et al. ${ }^{(29)}$ also found that mean RNFL thickness and number of retinal ganglion cells were redu- 
ced in morbid obesity. In the same study, no significant difference was found in central macular thickness, but CT was reduced. Using a caliper system, we measured significantly lower foveal RT was at both temporal and nasal $1500 \mathrm{~mm}$ locations in the morbidly obese group. In addition, CT was significantly reduced in most measured areas (all except temporal $1500 \mu \mathrm{m}$ ), in accord with Dogan et al. ${ }^{(29)}$. Yilmaz et al. also found reduced CT at the subfoveal area and up to $2000 \mu \mathrm{m}$ in both nasal and temporal directions from the fovea ${ }^{(26)}$. Unlike retina and optic nerve head vasculature, the choroidal blood supply is regulated autonomically, with noradrenaline from sympathetic efferent nerve activation reducing and NO from parasympathetic efferents increasing choroidal blood flow ${ }^{(30)}$. The effects of obesity on NO signaling in particular may explain the impact of obesity on CT because low NO values are observed in morbidly obese individuals. Further, there is a positive correlation between BMI and levels of the vasoconstrictors ET-1 and Ang-ll, suggesting that obesity-induced shifting of the vasodilator/vasoconstrictor balance (reduced NO and elevated ET-1 and Ang-ll) can affect CT. Spearman's correlation analysis revealed negative correlations of $\mathrm{BMl}$ and weight (but not height). Yilmaz et al. also found negative correlations of between $\mathrm{CT}$ and both BMI and weight $^{(26)}$. However, Yumusak et al. ${ }^{(31)}$ reported a positive correlation between BMI and CT in class two obese women, suggest that factors such as sex and severity of obesity may influence the relationship between BMI and choroidal blood flow.

The major strength of our study is the sample size. To our best knowledge, this is the largest -scale study conducted to date on the ocular effects of obesity in the absence of related diseases. Moreover, both anterior and posterior segment findings were evaluated in detail. Alternatively, the present study is limited by the lack of biochemical blood parameter measures. Another limitation is that we did not evaluate obstructive sleep apnea syndrome or obesity hypoventilation syndrome, and these disorders may also impact ocular function.

In conclusion, uncorrected IOP was significantly higher in the morbidly obese compared to matched controls with normal BMI. Corrected IOP, CCT, AL, and ACD did not differ significantly between groups, but regional decreases in RNFL thickness and RT were observed as well as more pervasive decreases in CT. IOP elevation and RNFL thinning in morbidly obese adults may increase the risks of glaucoma and optic neuropathy.

\section{REFERENCES}

1. James PT. Obesity: the worldwide epidemic. Clin Dermatol. 2004; 22(4):276-80.

2. Lobstein T, Baur L, Uauy R; IASO International Obesity Task Force. Obesity in children and young people: a crisis in public health. Obes Rev. 2004;5(Suppl 1):4-104.

3. Kennedy RL, Chokkalingham K, Srinivasan R. Obesity in the elderly: who should we be treating, and why, and how? Curr Opin Clin Nutr Metab Care. 2004;7(1):3-9.

4. Flegal KM, Graubard BI, Williamson DF, Gail MH. Excess deaths associated with underweight, overweight, and obesity. JAMA. 2005;293(15):1861-7.

5. Bergman B, Nilsson-Ehle H, Sjöstrand J. Ocular changes, risk markers for eye disorders and effects of cataract surgery in elderly people: a study of an urban Swedish population followed from 70 to 97 years of age. Acta Ophthalmol Scand. 2004;82(2):166-74.

6. Cheung N, Wong TY. Obesity and eye diseases. Surv Ophthalmol. 2007;52(2):180-95.

7. Wilson MR, Hertzmark E, Walker AM, Childs-Shaw K, Epstein DL. A case-control study of risk factors in open angle glaucoma. Arch Ophthalmol. 1987;105(8):1066-71.

8. Carel RS, Korczyn AD, Rock M, Goya l. Association between ocular pressure and certain health parameters. Ophthalmology. 1984; 91(4):311-4.

9. Klein BE, Klein R, Linton KL. Intraocular pressure in an American community. The Beaver Dam Eye Study. Invest Ophthalmol Vis Sci. 1992;33(7):2224-8.

10. Wu SY, Leske MC. Associations with intraocular pressure in the Barbados Eye Study. Arch Ophthalmol. 1997;115(12):1572-6.

11. Shiose Y. The aging effect on intraocular pressure in an apparently normal population. Arch Ophthalmol. 1984;102(6):883-7.

12. Stojanov O, Stokić E, Sveljo O, Naumović N. The influence of retrobulbar adipose tissue volume upon intraocular pressure in obesity. Vojnosanit Pregl. 2013;70(5):469-76.

13. Gunes A, Uzun F, Karaca EE, Kalaycı M. Evaluation of anterior segment parameters in obesity. Korean J Ophthalmol. 2015;29(4): 220-5.

14. Jang HD, Kim DH, Han K, Ha SG, Kim YH, Kim JW, et al. Relationship between intraocular pressure and parameters of obesity in Korean adults: the 2008-2010 Korea National Health and Nutrition Examination Survey. Curr Eye Res. 2015;40(10):1008-17.

15. Zang EA, Wynder EL. The association between body mass index and the relative frequencies of diseases in a sample of hospitalized patients. Nutr Cancer. 1994;21(3):247-61.

16. Gasser P, Stümpfig D, Schötzau A, Ackermann-Liebrich U, Flammer J. Body mass index in glaucoma. J Glaucoma. 1999;8(1):8-11.

17. Wolfs RC, Klaver CC, Vingerling JR, Grobbee DE, Hofman A, de Jong PT. Distribution of central corneal thickness and its association with intraocular pressure: the Rotterdam Study. Am J Ophthalmol. 1997;123(6):767-72.

18. Bron AM, Creuzot-Garcher C, Goudeau-Boutillon S, d'Athis P. Falsely elevated intraocular pressure due to increased central corneal thickness. Graefes Arch Clin Exp Ophthalmol. 1999;237(3):220-4.

19. Feltgen N, Leifert D, Funk J. Correlation between central corneal thickness, applanation tonometry, and direct intracameral IOP readings. Br J Ophthalmol. 2001;85(1):85-7.

20. Shiose Y, Kawase Y. A new approach to stratified normal intraocular pressure in a general population. Am J Ophthalmol. 1986;101(6): 714-21.

21. Halpern DL, Grosskreutz CL. Glaucomatous optic neuropathy: mechanisms of disease. Ophthalmol Clin North Am. 2002;15(1):61-8. 
22. Dielemans I, Vingerling JR, Wolfs RC, Hofman A, Grobbee DE, de Jong PT. The prevalence of primary open-angle glaucoma in a population-based study in The Netherlands. The Rotterdam Study. Ophthalmology. 1994;101(11):1851-5.

23. Maier PC, Funk J, Schwarzer G, Antes G, Falck-Ytter YT. Treatment of ocular hypertension and open angle glaucoma: meta-analysis of randomised controlled trials. BMJ. 2005;331(7509):134.

24. Grieshaber MC, Flammer J. Blood flow in glaucoma. Curr Opin Ophthalmol. 2005;16(2):79-83.

25. Newman-Casey PA, Talwar N, Nan B, Musch DC, Stein JD. The relationship between components of metabolic syndrome and open-angle glaucoma. Ophthalmology. 2011;118(7):1318-26.

26. Yilmaz l, Ozkaya A, Kocamaz M, Ahmet S, Ozkaya HM, Yasa D, et al. Correlation of choroidal thickness and body mass index. Retina. 2015;35(10):2085-90.

27. Su DH, Wong TY, Foster PJ, Tay WT, Saw SM, Aung T. Central cor- neal thickness and its associations with ocular and systemic factors: the Singapore Malay Eye Study. Am J Ophthalmol. 2009;147(4): 709-716.e1.

28. Spaide RF, Koizumi H, Pozzoni MC. Enhanced depth imaging spectral-domain optical coherence tomography. Am J Ophthalmol. 2008;146(4):496-500.

29. Dogan B, Kazim Erol M, Dogan U, Habibi M, Bulbuller N, Turgut Coban D, et al. The retinal nerve fiber layer, choroidal thickness, and central macular thickness in morbid obesity: an evaluation using spectral-domain optical coherence tomography. Eur Rev Med Pharmacol Sci. 2016;20(5):886-91.

30. Nilsson SF. Nitric oxide as a mediator of parasympathetic vasodilation in ocular and extraocular tissues in the rabbit. Invest Ophthalmol Vis Sci. 1996;37(10):2110-9.

31. Yumusak E, Ornek K, Durmaz SA, Cifci A, Guler HA, Bacanli Z. Choroidal thickness in obese women. BMC Ophthalmol. 2016; 16(1):48. 